\title{
Perkembangan dan Faktor-faktor yang Memengaruhi Tingkat Kemandirian Pasien Strok Selama Rawat Inap di Yogyakarta berdasar atas Skor Modifikasi Indeks Barthel
}

\author{
Nur Chayati, Dwi Puji Putranti, Erfin Firmawati \\ Program Studi Ilmu Keperawatan, Fakultas Kedokteran dan Ilmu Kesehatan \\ Universitas Muhammadiyah Yogyakarta, Indonesia
}

\begin{abstract}
Abstrak
Strok adalah gangguan fungsional otak fokal maupun global, bersifat akut, terjadi lebih dari 24 jam, berasal dari gangguan aliran darah otak dan bukan disebabkan oleh gangguan peredaran darah otak. Salah satu dampak dari strok adalah kelemahan anggota gerak baik hemiplegia atau hemiparesis sehingga mengganggu kemandirian pasien dalam aktivitas kehidupan sehari-hari (AKS). Tujuan penelitian ini mengetahui perkembangan tingkat kemandirian pasien strok berdasar atas skor Modifikasi Indeks Barthel serta faktor-faktor yang memengaruhi tingkat kemandirian pasien. Penelitian dilakukan di rumah sakit PKU Muhammadiyah Yogyakarta dan Rumah Sakit PKU Muhammadiyah Gamping pada bulan Mei hingga Juni 2016. Penelitian dilakukan dengan desain prospective longitudinal. Sejumlah 42 responden dipilih melalui accidental sampling. Instrumen yang digunakan adalah kuesioner Modifikasi Indeks Barthel. Data dianalisis dengan regresi logistik berganda. Hasil penelitian menunjukkan untuk pasien strok perdarahan, pada saat masuk rumah sakit mayoritas dengan kondisi tingkat ketergantungan total (44\%) dan pada saat keluar sakit sebagian besar menjadi tingkat ketergantungan parah (44\%). Untuk pasien dengan strok iskemik, saat masuk rumah sakit mayoritas juga berada pada tingkat ketergantungan total (49\%) dan terjadi perbaikan kondisi menjadi tingkat ketergantungan parah (42\%) pada saat keluar rumah sakit. Variabel lama rawat inap berhubungan secara signifikan terhadap skor Modifikasi Indeks Barthel $(\mathrm{p}<0,05)$. Tidak ada faktor yang paling dominan berpengaruh terhadap skor Modifikasi Indeks Barthel pasien strok.
\end{abstract}

Kata kunci: Aktivitas kehidupan sehari-hari, modifikasi indeks barthel, strok

\section{Development and Factors Affecting the Level of Independence of Stroke Patients During Hospitalization in Yogyakarta based on Modified Barthel Index Score}

\begin{abstract}
Stroke is a focal or global brain functional disorder which occur more than 24 hours and originating from a disruption of cerebral blood flow which is not caused by cerebral circulatory disorders. Consequences of stroke are extremity disability, hemiplegia, or hemiparesis. Furthermore, stroke makes it difficult for patients to do activities of daily life (ADL). The aim of this study was to determine the DLA independency level of stroke patient based on the Modified of Barthel Index score and to analyze the determinants that affect patient's dependency level. The study was conducted at PKU Muhammadiyah Yogyakarta Hospital and PKU Muhammadiyah Gamping Hospital in May to June 2016. This was a prospective longitudinal study on forty two respondents selected through accidental sampling. Barthel Index Modification instrument was used to measure the ADL independency level. Data were analyzed by multiple logistic regression. Majority of hemorrhagic stroke patients had total dependency when they were admitted to hospital (44.4\%) which improved to moderate dependency when they were discharged (44.4\%). Meanwhile, ischemic stroke patients were in total dependency the first time they came to hospital (44.4\%) and they also improved to severe dependency at discharge (42.4\%). Length of hospital stay has a significant correlation with Barthel Index score $(\mathrm{p}<0.05)$. None of the variables affects the Modified of Barthel Index score dominantly.
\end{abstract}

Key words: Activities of daily living, modified of barthel index, stroke

Korespondensi: Nur Chayati, S.Kep.,Ns.,M.Kep., Program Studi Ilmu Keperawatan, Fakultas Kedokteran dan Ilmu Kesehatan Universitas Muhammadiyah Yogyakarta, Email: nchayati1983@gmail.com 


\section{Pendahuluan}

Strok menjadi tiga penyebab kematian utama yang didefinisikan sebagai gangguan fungsional otak akut fokal maupun global yang mengarah ke kematian. ${ }^{1}$ Angka kejadian strok pada tahun 2010 mencapai 33 juta jiwa. Benua Asia berkonstribusi 66 persen, sedangkan Asia Tenggara menempati peringkat kedua sebagai benua yang memiliki angka kejadian strok terbanyak, yakni 4,5 juta jiwa atau sekitar $14,6 \% .{ }^{2}$ Indonesia menunjukkan peningkatan prevalensi strok dari 8,3 per 1.000 pada tahun 2007 menjadi 12,1 per 1.000 pada tahun 2013. Yogyakarta menempati peringkat kedua sebagai provinsi dengan jumlah penderita strok terbanyak di Indonesia. ${ }^{3}$

Strok disebabkan oleh gangguan aliran darah ke otakakibatpembuluh darah atau penyumbatan aliran darah ke otak sehingga menyebabkan fungsi otak hilang serta dampak kecacatan yang memengaruhi produktivitas dan kemandirian pasien. ${ }^{4}$ Dampak kecacatan yang paling banyak diderita pasien strok adalah kelumpuhan dalam bentuk hemiplegia (kelumpuhan pada satu tangan atau satu kaki atau bahkan satu sisi wajah) ataupun hemiparesis (kelemahan, tidak sepenuhnya lumpuh pada satu tangan atau satu kaki atau satu sisi wajah) yang disebabkan oleh jaringan otak rusak pada sisi berlawanan dari anggota tubuh. ${ }^{4}$ Pasien strok dengan hemiplegia atau hemiparesis memiliki angka ketergantungan yang tinggi dalam melaksanakan aktivitas kehidupan sehari-hari atau AKS. ${ }^{5}$ Ketergantungan dalam melakukan AKS jika tidak ditangani akan menimbulkan reaksi psikologis seperti depresi dan penurunan kualitas hidup yang secara tidak langsung memengaruhi aspek fisiologis pada pasien strok. Depresi pada pasien strok menyebabkan perlambatan pemulihan disabilitas fungsi AKS. ${ }^{6,7}$

Beberapa faktor yang dapat memengaruhi kemandirian AKS pada pasien strok antara lain usia, tingkat keparahan strok, dan status fungsional AKS pada saat masuk rumah sakit. ${ }^{8}$ Faktor demografi lain yang memengaruhi kemandirian fisik pasien dalam penelitian Ghazali dkk. ${ }^{9}$ adalah jenis kelamin, agama, status pernikahan, tingkat pendidikan, lingkungan tempat tinggal, sumber pembiayaan, efikasi diri, dan tipe caregiver. Untuk faktor klinis lain yang juga turut berperan meliputi jumlah serangan ulang strok, lokasi strok (otak kanan atau kiri), serta jenis terapi baik terapi medis maupun terapi alternatif yang diterima.

Usia yang bertambah dapat memperlambat perbaikan kemandirian oleh karena penurunan kemampuan fisik akibat proses menua. Semakin tinggi tingkat keparahan strok saat masuk rumah sakit maka akan memperlambat proses rehabilitasi pasien. Status fungsional AKS pada saat masuk rumah sakit berfungsi memprediksi hasil luaran fungsi AKS pada saat pemulangan pasien yang dilengkapi dalam bentuk rencana pemulangan pasien (discharge planning). ${ }^{8}$

Peran family caregiver juga memengaruhi luaran kemandirian pada pasien strok. Pasien yang mendapatkan sistem dukungan sosial dan perawatan dari keluarga yang baik akan mempercepat pemulihan fungsi AKS pasien. ${ }^{10}$ Tingkat pendidikan family caregiver akan memengaruhi pengetahuan dan perilaku family caregiver dalam merawat pasien strok. ${ }^{11}$ Semakin tinggi tingkat pendidikan family caregiver maka semakin baik perilaku perawatan pasien strok. ${ }^{11}$ Dalam penelitian ini, peneliti hanya menganalisis faktor usia, jenis kelamin, jenis strok, jenis kelumpuhan yang dialami (hemiplegia atau hemiparesis), dan lama rawat inap dikaitkan dengan tingkat kemandirian pasien. Pemilihan faktor-faktor ini didasarkan pada kesesuaian dengan area keperawatan dan tersedianya data dalam rekam medis.

Perawat sebagai salah satu tenaga kesehatan mempunyai peranan penting dalam menangani ketergantungan AKS pasien strok secara cepat. ${ }^{12}$ Peran tersebut meliputi mengkaji tingkat kemandirian AKS, melakukan pendampingan, dan memberikan bantuan pemenuhan AKS seperti personal hygiene, pemenuhan nutrisi, berpakaian, dan mobilisasi. ${ }^{12,13}$

Pengkajian AKS pada pasien strok merupakan salah satu hal penting untuk menentukan intervensi dan juga implementasi keperawatan yang tepat. Instrumen pengkajian AKS yang paling sering dipergunakan adalah Indeks Barthel. ${ }^{14,15}$. Dalam penelitian ini menggunakan instrumen Modifikasi Indeks Barthel yang telah dialihbahasakan ke bahasa Indonesia dan diteliti validitas reliabitasnya oleh Supraptiningsih. ${ }^{16}$ Hasil penelitian menyatakan bahwa instrumen modifikasi Indeks Barthel dapat digunakan di Indonesia dengan nilai koefisien Kappa 0,70 dengan interpretasi kesepakatan yang besar. ${ }^{16}$

Penelitian ini bertujuan mengetahui tingkat ketergantungan pasien strok berdasar atas skor Modifikasi Indeks Barthel serta menganalisis faktor yang paling dominan memengaruhi tingkat kemandirian pasien strok selama rawat inap. 


\section{Metode}

Penelitian ini merupakan penelitian kuantitatif dengan rancangan prospective longitudinal. Pengukuran tingkat kemandirian diambil sekali setiap hari pada siang hari sejak pasien masuk Rumah Sakit sampai keluar rumah sakit dan dibatasi hanya di bangsal perawatan. Penelitian dilakukan di rumah sakit PKU Muhammadiyah Yogyakarta dan rumah sakit PKU Muhammadiyah Gamping pada bulan Mei hingga Juni 2016. Penelitian ini dinyatakan layak etik oleh Komite Etik Penelitian Kesehatan Fakultas Kedokteran dan Ilmu Kesehatan Universitas Muhammadiyah Yogyakarta dengan Nomor: 171/EP-FKIK-UMY/ V/2016.

Populasi pasien strok berjumlah 47 pasien dalam 1 bulan. Besar sampel dalam penelitian ini adalah 42 pasien yang dipilih melalui accidental sampling dengan kriteria inklusi pasien strok hemoragik atau iskemik berdasar atas data pada rekam medis, bersedia menjadi responden, dan pasien yang didampingi oleh anggota keluarga yang berperan sebagai family caregiver selama menjalani rawat inap.

Data yang telah diambil meliputi usia, jenis kelamin, jenis strok, jenis kelumpuhan yang dialami (hemiplegia atau hemiparesis), lama rawat inap, dan tingkat ketergantungan pasien. Semua data diambil dari rekam medis kecuali tingkat kemandirian diperoleh dari pengkajian pasien secara langsung. Tingkat ketergantungan dibagi menjadi lima tingkatan berdasar atas skor Modifikasi Indeks Barthel, yaitu skor 0-20 ketergantungan total, skor 21-60 ketergantungan berat, skor 61-90 ketergantungan sedang, skor 91-99 ketergantungan minimal, dan skor 100 keadaan mandiri.

Data dianalisis secara multivariat yang didahului dengan analisis univariat dan bivariat. Analisis univariat mempergunakan analisis deskriptif berupa distribusi frekuensi dan nilai mean. Analisis bivariat dengan Uji Spearman Rho digunakan untuk mengetahui hubungan antara karakteristik pasien dan skor Modifikasi Indeks Barthel pasien. Analisis multivariat bertujuan menguji faktor yang paling dominan memengaruhi tingkat kemandirian pasien menggunakan regresi logistik berganda.

\section{Hasil}

Dari 42 pasien strok yang diamati sebagian besar adalah usia lanjut berjenis kelamin laki-laki. Jenis strok yang dialami kebanyakan adalah strok

\begin{tabular}{cc}
$\begin{array}{c}\text { Tabel } 1 \\
\text { Data Umum Pasien Stroke } \\
\text { berdasar atas Usia, Jenis Kelamin, } \\
\text { Jenis Strok, dan Jenis Kelumpuhan }\end{array}$ \\
\hline Karakteristik & Frekuensi (n) \\
\hline Usia (tahun) & $1(2 \%)$ \\
$35-44$ & $8(19 \%)$ \\
$45-54$ & $16(38 \%)$ \\
$55-64$ & $17(41 \%)$ \\
$>64$ & \\
Jenis kelamin & $24(57 \%)$ \\
Laki-laki & $18(43 \%)$ \\
Perempuan & \\
Jenis strok & $9(21 \%)$ \\
Hemoragik & $33(79 \%)$ \\
Iskemik & \\
Jenis kelumpuhan & $2(5 \%)$ \\
Hemiplegia & $40(95 \%)$ \\
Hemiparesis &
\end{tabular}

iskemik serta jenis kelemahan yang diderita adalah hemiparesis (Tabel 1). Pasien menjalani rawat inap rerata selama 4 hari, namun rawat inap paling lama selama 11 hari pada penderita strok perdarahan (Tabel 2).

Hasil penghitungan skor Modifikasi Indeks Barthel diperoleh data bahwa untuk pasien strok perdarahan pada saat awal masuk rumah sakit, sebagian besar dengan kategori ketergantungan total dan sedang. Namun, setelah menjalani perawatan, tingkat ketergantungan pasien telah membaik yang dibuktikan dengan penurunan jumlah pasien dengan ketergantungan total dan sedang diimbangi peningkatan jumlah pasien dengan kategori ketergantungan ringan dan mandiri. Untuk kategori strok iskemik sebagian besar pasien dalam kategori ketergantungan total saat masuk rumah sakit dan setelah menjalani perawatan terjadi penurunan tingkat ketergantungan menjadi lebih banyak dalam kategori sedang, ringan, dan mndiri (Tabel 3).

Tabel 4 memperlihatkan bahwa kondisi akhir pasien strok perdarahan lebih banyak mengalami penurunan tingkat ketergantungan atau peningkatan tingkat kemandirian meskipun ada yang kondisinya menetap, namun jumlahnya sedikit. Untuk strok iskemik kondisi akhir pasien bervariasi, sebagian mengalami penurunan tingkat ketergantungan, sebagian lagi memiliki tingkat ketergantungan yang sama dengan saat masuk rumah sakit, serta ada sejumlah kecil pasien yang justru mengalami perburukan 
Tabel 2 Distribusi Frekuensi Lama Rawat Inap Pasien Strok di RS PKU Muhammadiyah Yogyakarta dan RS PKU Muhammadiyah Gamping

\begin{tabular}{lcccccc}
\hline \multicolumn{1}{c}{ Strok } & $\begin{array}{c}\text { Frekuensi } \\
(\mathbf{n = 4 2})\end{array}$ & Mean & Median & Modus & $\begin{array}{c}\text { Min.- } \\
\text { Maks. }\end{array}$ & $\begin{array}{c}\text { 95\% } \\
\text { IK }\end{array}$ \\
\hline Lama rawat inap (hari) & & & & & & \\
Strok hemoragik & 9 & 4,67 & 5 & 2 & $2-11$ & $2,29-7,03$ \\
Strok iskemik & 33 & 4,06 & 4 & 4 & $1-8$ & $3,47-4,64$ \\
\hline
\end{tabular}

Sumber: Data primer

(peningkatan tingkat ketergantungan).

Sebelum dilakukan analisis bivariat maka dilakukan uji normalitas terhadap data-data yang berskala numerik dan diperoleh hasil untuk variabel usia $\mathrm{p}=0,069$; jumlah hari rawat $\mathrm{p}=0,000$; dan skor Modifikasi Indeks Barthel $\mathrm{p}=0,002$. Hasil uji normalitas tampak bahwa hanya variabel usia yang terdistribusi normal. Analisis bivariat antara usia dan skor Modifikasi Indeks Barthel dilakukan dengan Uji Korelasi Pearson. Untuk analisis hubungan antara jumlah hari rawat dengan skor Modifikasi Indeks Barthel menggunakan Uji Korelasi Spearman Rho.

Untuk menganalisis hubungan jenis strok dan jenis kelamin dengan skor Modifikasi Indeks Barthel dilakukan Uji Pearson Chi-Square. Berdasar atas nilai $\mathrm{p}$ antara jenis atau tipe strok dan skor Modifikasi Indeks Barthel tidak signifikan $(p=0,862)$. Begitu juga variabel jenis kelamin dengan skor Modifikasi Indeks Barthel tidak signifikan $(p=0,773)$. Dapat disimpulkan bahwa dari uji bivariat hanya variabel lama rawat inap yang berhubungan signifikan dengan skor Modifikasi Indeks Barthel.

Penentuan variabel yang paling memengaruhi skor Modifikasi Indeks Barthel dilakukan dengan uji regresi logistik. Langkah-langkah melakukan uji regresi logistik diawali dengan seleksi variabel kandidat (semua variabel dibuat dalam skala kategorik). Hasil seleksi variabel kandidat dituangkan dalam Tabel 6.

Berdasar atas Tabel 6 dari tahap pemilihan variabel kandidat diperoleh data bahwa semua variabel memiliki nilai signifikansi $(p>0,25)$ sehingga varibel tersebut tidak memenuhi syarat untuk dilakukan uji regresi logistik. Dari uji ini dapat diambil simpulan bahwa tidak ada variabel yang berpengaruh dominan terhadap skor Modifikasi Indeks Barthel pasien strok.

\section{Pembahasan}

Tingkat ketergantungan AKS baik pada pasien strok hemoragik maupun strok iskemik saat masuk rumah sakit sebagian besar berada pada tingkat ketergantungan total. Pasien strok hemoragik maupun iskemik memasuki masamasa kritis dalam perburukan kondisi strok saat 48-72 jam pertamansehingga kondisi klinis

Tabel 3 Distribusi Frekuensi Tingkat Ketergantungan AKS Pasien Strok Saat Masuk Rumah Sakit sampai Keluar Rumah Sakit berdasar atas Jenis Strok di RS PKU Muhammadiyah Yogyakarta dan Gamping

\begin{tabular}{|c|c|c|c|c|c|}
\hline \multirow{2}{*}{$\begin{array}{c}\text { Tingkat } \\
\text { Ketergantungan }\end{array}$} & \multicolumn{3}{|c|}{ Masuk Rumah Sakit } & \multicolumn{2}{|c|}{ Keluar Rumah Sakit } \\
\hline & Kategori & $\begin{array}{l}\text { Frekuensi } \\
\text { (n) }\end{array}$ & $\begin{array}{c}\text { Persentase } \\
\text { (\%) }\end{array}$ & $\begin{array}{l}\text { Frekuensi } \\
\text { (n) }\end{array}$ & $\begin{array}{c}\text { Persentase } \\
\text { (\%) }\end{array}$ \\
\hline \multirow{5}{*}{ Pasien strok hemoragik } & Total & 4 & 44 & 1 & 11 \\
\hline & Parah & 1 & 11 & 4 & 44 \\
\hline & Sedang & 4 & 44 & 2 & 22 \\
\hline & Ringan & 0 & 0 & 1 & 11 \\
\hline & Mandiri & 0 & 0 & 1 & 11 \\
\hline \multirow{5}{*}{ Pasien strok iskemik } & Total & 16 & 49 & 9 & 27 \\
\hline & Parah & 11 & 33 & 14 & 42 \\
\hline & Sedang & 6 & 18 & 8 & 24 \\
\hline & Ringan & 0 & 0 & 9 & 27 \\
\hline & Mandiri & 0 & 0 & 1 & 3 \\
\hline
\end{tabular}


N. Chayati dkk.: Perkembangan dan Faktor-faktor yang Memengaruhi Tingkat Kemandirian Pasien Strok Selama Rawat Inap di Yogyakarta berdasar atas Skor Modifikasi Indeks Barthel

Tabel 4 Distribusi Frekuensi Perubahan Status Tingkat Ketergantungan AKS Pasien Strok Saat Masuk Rumah Sakit sampai Keluar Rumah Sakit berdasar atas Jenis Strok di RS PKU Muhammadiyah Yogyakarta dan RS PKU Muhammadiyah Gamping

\begin{tabular}{|c|c|c|c|}
\hline $\begin{array}{c}\text { Perubahan Status Tingkat } \\
\text { Ketergantungan }\end{array}$ & Kategori & Frekuensi (n) & $\begin{array}{c}\text { Persentase } \\
(\%)\end{array}$ \\
\hline \multicolumn{4}{|l|}{$\begin{array}{l}\text { AKS pasien strok hemoragik } \\
\text { Menurun }\end{array}$} \\
\hline & Total-parah & 3 & 33 \\
\hline & Parah-sedang & 0 & 0 \\
\hline & Sedang-ringan & 1 & 11 \\
\hline & Sedang-mandiri & 1 & 11 \\
\hline \multirow{6}{*}{ Tetap } & Total-total & 1 & 11 \\
\hline & Parah-parah & 1 & 11 \\
\hline & Sedang-sedang & 2 & 22 \\
\hline & Ringan-ringan & 0 & 0 \\
\hline & Mandiri-mandiri & 0 & 0 \\
\hline & Parah-total & 0 & 0 \\
\hline \multirow[t]{2}{*}{ Meningkat } & Ringan-sedang & 0 & 0 \\
\hline & Mandiri-ringan & 0 & 0 \\
\hline \multicolumn{4}{|l|}{$\begin{array}{l}\text { AKS pasien strok iskemik } \\
\text { Menurun }\end{array}$} \\
\hline & Total-parah & 8 & 24,2 \\
\hline & Parah-sedang & 3 & 9,1 \\
\hline & Sedang-ringan & 2 & 6,1 \\
\hline & Sedang-mandiri & 2 & 6,1 \\
\hline \multirow{5}{*}{ Tetap } & Total-total & 7 & 21,2 \\
\hline & Parah-parah & 4 & 12,1 \\
\hline & Sedang-sedang & 5 & 15,2 \\
\hline & Ringan-ringan & 0 & 0 \\
\hline & Mandiri-mandiri & 0 & 0 \\
\hline \multirow{3}{*}{ Meningkat } & Parah-total & 2 & 6,1 \\
\hline & Ringan-sedang & 0 & 0 \\
\hline & Mandiri-ringan & 0 & 0 \\
\hline
\end{tabular}

strok baik strok iskemik maupun hemoragik paling buruk berada pada hari-hari pertama pascaserangan strok. Hal tersebut ditandai dengan penurunan kesadaran dan kelumpuhan motorik yang merupakan dampak terbesar penyakit strok. ${ }^{17}$ Penelitian yang dilakukan oleh Carlo $^{18}$ mendapatkan hasil yang serupa dengan penelitian ini, yakni pasien strok dengan tingkat ketergantungan total merupakan kelompok

\section{Tabel 5 Hubungan Usia dan Lama Rawat} Inap dengan Skor Index Barthel

\begin{tabular}{lccc}
\hline \multicolumn{1}{c}{ Variabel } & n & Nilai $\mathbf{p}$ & r \\
\hline Usia & 42 & 0,588 & \\
Lama rawat inap & 42 & $0,002^{*}$ & 0,468 \\
\hline
\end{tabular}
p $<0,05$ pasien dengan jumlah paling banyak pada saat masuk rumah sakit.

Usia memegang peranan yang penting dalam perbaikan kondisi pasien strok. Semakin tua usia penderita maka proses perbaikan kondisi akan membutuhkan waktu yang lebih lama karena penurunan kemampuan fisik pada usia lanjut.. ${ }^{8}$ Dilihat dari jenis strok, pasien strok

\section{Tabel 6 Pemilihan Variabel Kandidat}

\begin{tabular}{lc}
\hline \multicolumn{1}{c}{ Variabel } & Nilai $\mathbf{p}$ \\
\hline Usia & 0,787 \\
Jenis strok & 0,862 \\
Jenis kelamin & 0,773 \\
Lama rawat inap & 0,316 \\
\hline $\mathrm{p}<0,25$ &
\end{tabular}


hemoragik menjalani rawat inap lebih panjang daripada strok iskemik. Strok jenis hemoragik atau perdarahan merupakan strok dengan perburukan kondisi klinis yang lebih tinggi dibanding dengan strok iskemik. ${ }^{19}$ Perburukan kondisi tersebut akan memperlambat proses rehabilitasi sebagai intervensi utama pemulihan kemampuan AKS. ${ }^{8}$

Pada saat keluar rumah sakit, pasien strok hemoragik dan iskemik yang sebelumnya berada pada tingkat ketergantungan total mengalami peningkatan menjadi tingkat ketergantungan parah. Meskipun terjadi penurunan tingkat ketergantungan AKS, tetapi penurunan yang terjadi tidak terlalu signifikan. Data tersebut selaras dengan penelitian sebelumnya yang menyatakan bahwa pasien strok yang berada pada tingkat ketergantungan total dan parah masih menjadi kelompok pasien dengan jumlah terbanyak saat keluar rumah sakit dan tidak mengalami peningkatan yang signifikan. ${ }^{18}$

Kemampuan AKS pada saat masuk rumah sakit dan selama menjalani rawat inap dapat memprediksi skor AKS atau outcome skor AKS pada saat keluar rumah sakit. Semakin tinggi tingkat ketergantungan AKS pada saat masuk rumah sakit, perubahan status tingkat ketergantungan AKS atau outcome skor AKS pada saat keluar rumah sakit tidak akan jauh berbeda. $^{8}$

Hasil penelitian menunjukkan bahwa hanya variabel lama rawat inap yang berhubungan signifikan dengan skor Modifikasi Indeks Barthel. Hal ini dapat dijelaskan bahwa dengan waktu perawatan yang mencukupi maka pasien akan lebih lama mendapatkan terapi pengobatan dan pemantauan yang intensif.

Pada penelitian ini menunjukkan bahwa rawat inap paling lama dijalani oleh pasien strok perdarahan/hemoragik, yaitu selama 11 hari. Strok perdarahan adalah jenis strok yang risiko terjadi perburukan klinis lebih banyak dibanding dengan strok iskemik. Terjadi perburukan kondisi tersebut menyebabkan proses rehabilitasi untuk pemulihan kemampuan AKS menjadi lebih panjang sehingga waktu yang dibutuhkan untuk rawat inap lebih lama. ${ }^{8}$

Terdapat beberapa penyakit penyerta juga memungkinkan dapat memengaruhi perubahan tingkat ketergantungan AKS. Menurut Junaidi ${ }^{20}$ pasien strok yang memiliki penyakit penyerta memiliki tingkat ketergantungan yang lebih tinggi dibanding dengan yang tidak memiliki penyakit penyerta sehingga pasien mengalami perlambatan dalam pemulihan fungsi AKS. Namun, pada penelitian ini tidak dilakukan pengumpulan data terkaitpenyakitpenyertayang dapat memperburuk tingkat ketergantungan pasien strok seperti hipertensi, diabetes melitus, riwayat transient ischemic attack (TIA), dan komplikasi penyakit penyerta lainnya.

Tingkat kemandirian pasien di akhir rawat inap menunjukkan peningkatan hampir lima puluh persen dari kondisi awal. Berdasar atas analisis regresi tidak ada faktor yang paling dominan memengaruhi tingkat kemandirian pasien. Hal ini bukan karena tidak ada faktor yang paling mendominasi berdasar atas hasil statistik di proses regresi logistik, akan tetapi karena tidak ada variabel dalam penelitian ini yang masuk variabel kandidat atau variabel terpilih untuk diikutkan dalam uji regresi. Hal ini kemungkinan berkaitan dengan jumlah variabel yang diikutkan dalam penelitian ini sangat terbatas, hanya enam variabel, sementara faktorfaktor lain yang turut berperan terhadap skor tingkat kemandirian pasien tidak diteliti, seperti status serangan strok apakah ulangan atau strok akut, kondisi psikologis pasien, dukungan keluarga, dan jenis terapi.

Simpulan, perkembangan kemandirian pada pasien strok selama rawat inap menunjukkan peningkatan yang baik. Tidak ada faktor yang paling dominan dapat memengaruhi tingkat kemandirian pasien strok. Setidaknya ada tiga keterbatasan yang dapat diidentifikasi dalam penelitian ini. Pertama adalah tidak dikaji derajat keparahan strok saat awal rawat inap, obat-obatan atau intervensi lain yang diterima pasien, penyakit penyerta seperti diabetes melitus, hipertensi, riwayat strok sebelumnya, komplikasi penyakit penyerta lainnya. Kedua, kurang objektivitas jawaban kuesioner jika yang menjawab adalah family caregiver. Kebenaran informasi tingkat ketergantungan AKS pasien strok yang diberikan bersifat subjektif dari sudut pandang family caregiver bukan dari pasien strok secara langsung. Ketiga, metode observasi hanya dilakukan oleh peneliti tanpa melibatkan pihak kedua untuk mengorfirmasi hasil temuan. Tindak lanjut untuk penelitian berikutnya dapat tetap menggunakan metode longitudinal, namun perlu menambahkan beberapa data yang belum diambil dalam penelitian ini, serta melakukan konfirmasi hasil dengan petugas kesehatan penanggungjawab pasien.

\section{Ucapan Terima Kasih}

Ucapan terima kasih kepada LP3M Universitas Muhammadiyah Yogyakarta (UMY) yang telah 
memberikan dana penelitian ini melalui hibah internal penelitian UMY.

\section{Daftar Pustaka}

1. World Health Organization (WHO). Global status report on non-communicabel diseases. Geneva: WHO Press; 2014.

2. Woodward M, Tsukinoki-Murakami R, Murakami Y, Suh I, Fang X, Ueshima H. The epidemiology of stroke amongst women in the Asia-Pacific region. Womens Heal (1 Engl). 2011;7:305-17.

3. Kementerian Kesehatan Republik Indonesia. Laporan nasional riset kesehatan dasar 2018. Jakarta: DepKes RI; 2018.

4. Langhorne P, Bernhardt J, Kwakkel G. Stroke rehabilitation. Lancet. 2011;377(9778): 1693-1702. Tersedia dari: http://dx.doi. org/10.1016/S0140-6736(11)60325-5.

5. Miller EL, Murray L, Richards L, Zorowitz RD, Bakas T, Clark P. Comprehensive overview of nursing and interdisciplinary rehabilitation care of the strok patient: a scientific statement from the American Heart Association. Stroke. 2010;41:2402-48.

6. Guajardo VD, Terroni L, Sobreiro MDFM, Zerbini MIDS, Tinone G, Scaff M, dkk. The influence of depressive symptoms on quality of life after stroke: a prospective study. J Strok Cerebrovasc Dis. 2014;22(1):201-9.

7. Žikic RT, Divjak I, Jovićević M, Semnic M, Slankamenac P, Žarkov M, dkk. The effect of post stroke depression on functional outcome and quality of life. Acta Clin Croat. 2014;53(3):294-301.

8. Parekh I, Rhoda A. Functional outcomes of stroke patients admitted to a tertiary hospital in Western Cape, South Africa. South Africa J Physiother. 2013;69(2):10-4.

9. Ghazali SE, Zulkifly MFM, Din NC, Desa A, Ali RA. Hubungan antara faktor demografik dan klinikal dengan kefungsian fizikal pesakit stroke. Sains Kesihat Malaysia. 2016; 14(2):23-30.
10. Lutz B, Young M. Rethinking intervention strategies in strok family caregiving. Rehabil Nurs. 2010;35(4):152-60.

11. Hartati J. Hubungan tingkat pengetahuan dengan perilaku family caregiving dalam merawat pasien paska stroke di rumah. UIN Syarif Hidayatullah; 2012. Tersedia dari: http://repository.uinjkt.ac.id

12. Bjartmarz I, Jónsdóttir H, Hafsteinsdóttir TB. Implementation and feasibility of the stroke nursing guideline in the care of patients with strok: A mixed methods study. BMC Nurs. 2017;16(1):1-18.

13. Aadal L, Angel S, Dreyer P, Langhorn L, Pedersen BB. Nursing roles and functions in the inpatient neurorehabilitation of stroke patients: a literature review. J Neurosci Nurs. 2013;45(3):158-70.

14. National Stroke Foundation (NSF). Clinical guidelines for strok management; a quick guide for nursing. Melbourne: Stroke Foundation; 2010.

15. Kelloway L, Kras-Dupuis A, Martin-Gaspar C, Whiteman R, O’Farrell B, Maclsaac L, dkk. Stroke assessment across the continuum of care: guideline supplement. Ontario: Registered Nurse Association of Ontario; 2011.

16. Supraptiningsih. Reliabilitas modifikasi indeks barthel pada penderita stroke. [disertasi]. Yogyakarta: Universitas Gadjah Mada; 1993.

17. McCormack J, Reay H. Acute strok research: challenges and opportunities for nurses. Nurs Stand. 2013;27(32):39-45.

18. Carlo A Di, Lamassa M, Franceschini M, Bovis F, Cecconi L, Pournajaf S, dkk. Impact of acute-phase complications and interventions on 6-month survival after stroke. A prospective observational study. PLoS One. 2018;13(3):1-16.

19. Pinzon R. AWAS strok! pengertian, gejala, tindakan, perawatan, dan pencegahan. Yogyakarta: Andi; 2010.

20. Junaidi I. Strok: waspadai ancamannya. Yogyakarta: Andi Offset; 2011. 